\title{
Wave Attenuation at a Salt Marsh Margin: A Case Study of an Exposed Coast on the Yangtze Estuary
}

\author{
S. L. Yang • B. W. Shi • T. J. Bouma • T. Ysebaert • \\ X. X. Luo
}

Received: 5 January 2011 /Revised: 30 April 2011 / Accepted: 14 June 2011 /Published online: 6 July 2011

(C) The Author(s) 2011. This article is published with open access at Springerlink.com

\begin{abstract}
To quantify wave attenuation by (introduced) Spartina alterniflora vegetation at an exposed macrotidal coast in the Yangtze Estuary, China, wave parameters and water depth were measured during 13 consecutive tides at nine locations ranging from $10 \mathrm{~m}$ seaward to $50 \mathrm{~m}$ landward of the low marsh edge. During this period, the incident wave height ranged from $<0.1$ to $1.5 \mathrm{~m}$, the maximum of which is much higher than observed in other marsh areas around the world. Our measurements and calculations showed that the wave attenuation rate per unit distance was 1 to 2 magnitudes higher over the marsh than over an adjacent mudflat. Although the elevation gradient of the marsh margin was significantly higher than that of the adjacent mudflat, more than $80 \%$ of wave attenuation was ascribed to the presence of vegetation, suggesting that shoaling effects were of minor importance. On average, waves reaching the marsh were eliminated over a distance of $\sim 80 \mathrm{~m}$, although a marsh distance of $\geq 100 \mathrm{~m}$ was needed before the maximum height waves were fully attenuated during high tides. These attenuation distances were longer than those previously found in American salt marshes, mainly due to the macrotidal and exposed conditions at the present site. The ratio of water depth to plant height showed an inverse correlation with wave attenuation rate, indicating that plant height is a crucial factor determining the
\end{abstract}

S. L. Yang $(\bowtie) \cdot$ B. W. Shi $\cdot$ X. X. Luo

State Key Laboratory of Estuarine and Coastal Research,

East China Normal University,

3663 North Zhongshan Road,

Shanghai 200062, People's Republic of China

e-mail: slyang@sklec.ecnu.edu.cn

T. J. Bouma $\cdot$ T. Ysebaert

Netherlands Institute of Ecology (NIOO),

P.O. Box 140, 4400AC Yerseke, The Netherlands efficiency of wave attenuation. Consequently, the tall shoots of the introduced $S$. alterniflora makes this species much more efficient at attenuating waves than the shorter, native pioneer species in the Yangtze Estuary, and should therefore be considered as a factor in coastal management during the present era of sea-level rise and global change. We also found that wave attenuation across the salt marsh can be predicted using published models when a suitable coefficient is incorporated to account for drag, which varies in place and time due to differences in plant characteristics and abiotic conditions (i.e., bed gradient, initial water depth, and wave action).

Keywords Wave attenuation - Salt marsh · Tidal flat . Spartina alterniflora $\cdot$ Yangtze Estuary

\section{Introduction}

During the present era of sea-level rise and increasing storminess, sustainable coastal protection is of growing importance. The magnitude of wave energy that reaches the coastline is one of the most important criteria in the design of coastal defenses. It is widely recognized that salt marshes are able to significantly attenuate waves (Wayne 1976; Asano and Setoguchi 1996; Möller 2006). This buffering function is of great environmental and engineering significance (Leggett and Dixon 1994; Möller et al. 1999; Barbier et al. 2009). Many salt marshes have been lost in recent decades, mainly because of human activities (Goodwin et al. 2001). Furthermore, remaining salt marshes are at risk of drowning (Roman et al. 1997; Reed 2002) as a result of global sea-level rise (Douglas et al. 2001) and a local reduction in (riverine) sediment supply (Yang et al. 2006). The ability of salt marshes to accrete in response to sea-level 
rise by trapping sediment is strongly dependent on the attenuation of waves and currents (Friedrichs and Perry 2001; Leonard and Reed 2002; Bouma et al. 2005a). Hence, from the perspective of both coastal defense and salt marsh management, an in-depth understanding is needed of the way in which waves are attenuated by salt marshes. Compared with the large number of studies that have investigated currents in tidal wetlands (e.g. Leonard and Luther 1995; Shi et al. 1995; Allen 2000; Christiansen et al. 2000; Neumeier and Ciavola 2004; Bouma et al. 2005b and references therein), relatively few studies have focused on wave attenuation.

Flume experiments have shown that wave damping by salt marshes is strongly affected by vegetation characteristics (e.g., Bouma et al. 2005a, 2010). Flumes are, however, of limited use for studying the effect of flooding height on wave attenuation. In the field, temporal fluctuations in water levels (i.e., tides and storm surges) add to the complexity of wave attenuation processes. In addition, vegetation characteristics may vary seasonally and spatially. Such differences emphasize the importance of analyzing multiple field sites in order to obtain a general understanding of the role of marsh vegetation in wave dissipation. The few available field studies of wave attenuation have typically described observations made with a combination of either (a) short transects $(20 \mathrm{~m})$ with tall vegetation and relatively lowenergy waves (e.g. Wayne 1976; Knuston et al. 1982; Bouma et al. 2005a) or (b) long transects $(180 \mathrm{~m})$ with short vegetation and high-energy waves (e.g. Möller et al. 1999). There remains, however, a lack of knowledge on what stretch of vegetation is needed to attenuate large incoming waves in combination with tall vegetation and how this varies with flooding height.

In the present study on an exposed macrotidal coast in the Yangtze Estuary (Fig. 1), China, we aimed to gain a better insight of (a) the stretch of tall and dense Spartina marsh vegetation needed to attenuate large incoming waves; (b) the variability of wave attenuation in relation to abiotic conditions (i.e., flooding height, wind climate, and geomorphology); and (c) the applicability of current models in predicting wave attenuation across the salt marsh. A comparison is made with findings from microtidal and relatively sheltered sites in the USA and some macrotidal and exposed European sites colonized by much shorter vegetation.

\section{Field Setting}

Field measurements were made in an exposed mudflat-salt marsh transition zone, Eastern Chongming Island, Yangtze Estuary (Fig. 1). The estuary is characterized by a large quantity of fine-grained sediment from the Yangtze River
(Eisma 1998) and by irregular semidiurnal macrotides. At the Sheshan gauging station (Fig. 1b), the average tidal range is $2.6 \mathrm{~m}$, reaching $3.5-4.0 \mathrm{~m}$ during spring tides. Wind speed is $\sim 4 \mathrm{~m} / \mathrm{s}$ on average, with a maximum recorded speed of $36 \mathrm{~m} / \mathrm{s}$. At the estuary front $(\sim 5 \mathrm{~m}$ below the lowest astronomic tide), mean and maximum wave heights are 1.0 and $6.2 \mathrm{~m}$, respectively (Yang et al. 2001). The maximum width of the tidal wetland in Eastern Chongming is $8 \mathrm{~km}$, the upper portion $(\sim 3 \mathrm{~km})$ being salt marsh (Fig. 1c). In 2001, Spartina alterniflora was introduced to the northern marsh in Eastern Chongming with the aim of enhancing sediment accretion. Since then, Spartina has spread rapidly and replaced the much shorter $(\sim 50 \mathrm{~cm}$ in height), native pioneer species Scirpus mariqueter (Yang et al. 2008). The border between mudflat and marsh is indented, with tussocks occasionally found on the seaward side (Fig. 1d).

\section{Materials and Methods}

\section{Measurements}

We deployed wave sensors along transects across the transition of mudflat and marsh (Fig. 1d). In addition, measurements were made along a longshore transect designed to compare waves between a mudflat site (Site 3) and a marsh site (Site 4). Because of the limited number of available wave sensors (three), we measured five spatial configurations: Sites 1-4-5, 2-3-4, 4-5-6, 1-5-6, and 7-8-9. The elevation of each site was determined using a Real-Time Kinematic Global Positioning System (Ashtech, USA).

Waves and tidal flooding depths were measured over 13 tides around spring tide in November 2007 using selflogging wave sensors (Sea-Bird Electronics Inc., USA; SBE 2007). The instruments were programmed to measure (a) the water depth, by integrating $4 \mathrm{~Hz}$ pressure measurements over a 1-min period; and (b) waves (wave height, wave energy, and wave period) by taking $4-\mathrm{Hz}$ pressure measurements over a 128-s period (i.e., 512 measurements per burst) every $10 \mathrm{~min}$. The wave sensors were mounted $0.15 \mathrm{~m}$ above the sediment surface. Pressure-to-depth conversion was automatically performed by the instrument, and all relevant wave parameters were obtained using the manufacturer's software (SBE 2007). Testing among the wave sensors on the mudflat (S1, Fig. 1d) showed that the three instruments recorded equal water depths and that wave heights varied only by $0-3 \%$.

Plant height and stem density and diameter (basal, middle, and terminal) were obtained by sampling representative of $0.5 \times 0.5-\mathrm{m}$ plots. During floods, the submergence of the vegetation and wave propagation at high tides were observed visually from a boat at a distance of $\sim 50 \mathrm{~m}$. Mean 
Fig. 1 Location of the study area and observation sites. The red square in $(\mathbf{a}-\mathbf{c})$ indicates the area shown in the following panel. The distances between pairs of sites are as follows: Sites $1-2=7.5 \mathrm{~m}, 2-4=7.5 \mathrm{~m}$, $4-5=12.5 \mathrm{~m}, 5-6=31 \mathrm{~m}, 3-4=$ $13.0 \mathrm{~m}, 7-8=13.5 \mathrm{~m}$, and $8-9=$ $7.5 \mathrm{~m}$. Site 2 was on the mudflat, near the marsh edge. Site 8 was located at the center of a marsh tussock that had a diameter of $\sim 9 \mathrm{~m}$. Elevations above the lowest astronomic tide were as follows: $2.73 \mathrm{~m}$ (Site 1), $2.74 \mathrm{~m}$ (Site 2), $2.75 \mathrm{~m}$ (Site 3), $3.01 \mathrm{~m}$ (Site 4), $3.01 \mathrm{~m}$ (Site 5), $3.37 \mathrm{~m}$ (Site 6), $2.73 \mathrm{~m}$ (Site 7), $3.02 \mathrm{~m}$ (Site 8 ), and $2.86 \mathrm{~m}$ (Site 9). A small cliff of $\sim 0.3 \mathrm{~m}$ in height was present along the marsh edge and around the marsh tussock, which resulted in an abrupt increase in elevation from the mudflat to the marsh
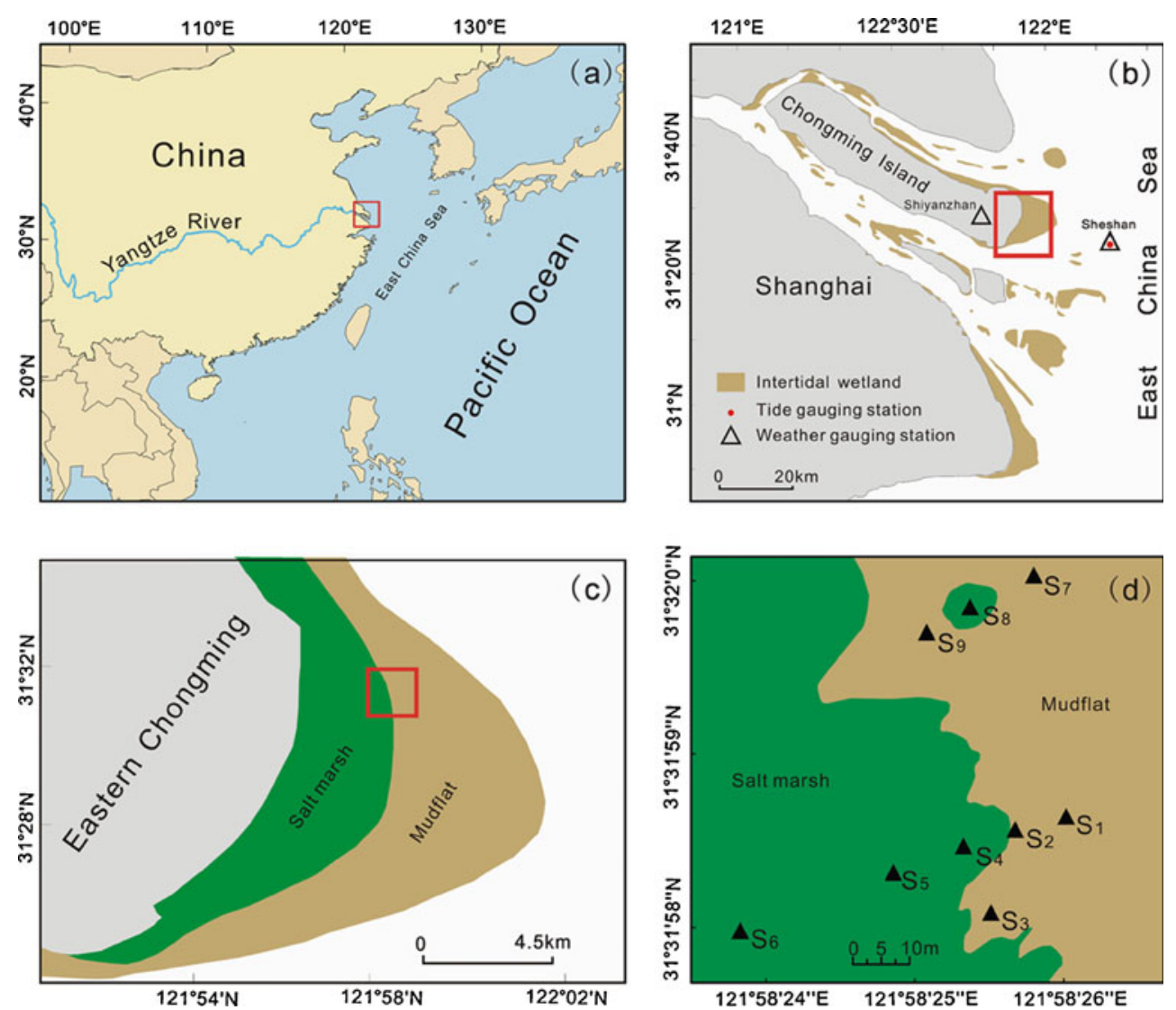

wind speed and direction, and tide level data were collected hourly from the Sheshan gauging station, located $20 \mathrm{~km}$ seaward of the study site; maximum wind speed data were collected from the Shiyanzhan weather station, located $15 \mathrm{~km}$ landward from the study site (Fig. 1b).

\section{Calculations}

Predictions of transmitted wave heights at the landward side of marsh transect were made using the Dean (1978) model and Knutson et al. (1982) model. Dean (1978) suggested that marsh plants are much like an array of vertical cylinders in a water column, expressed as follows:

$H_{2}=\frac{H_{1}}{1+A H_{1} L}$

where

$A=\frac{C_{D} D}{6 \pi S^{2} d}$

where $H_{2}$ is the transmitted wave height; $H_{1}$ is the incident wave height; $L$ is the length of the vegetation stand (seaward to landward) through which waves propagate; $C_{D}$ (approximately $\left.=1.0\right)$ is the drag coefficient associated with smooth, rigid, vertical cylinder; $D$ is the stem diameter; $S$ is the average spacing of stems (assumed to be on square centers; i.e., $S=1 /\left(P_{\mathrm{d}}\right)^{1 / 2}$ where $P_{\mathrm{d}}$ is stem density); and $d$ is the water depth.

To make the Dean (1978) model more applicable in the $S$. alterniflora marsh in Chesapeake Bay, USA, Knuston et al. (1982) modified the Dean (1978) model by adding a plant drag coefficient $C_{\mathrm{P}}$, which is assumed to be approximately 5:

$A=\frac{C_{\mathrm{D}} C_{\mathrm{P}} D}{3 \pi S^{2} d}$

Equation 3 differs from Eq. 2 not only because of the introduction of $C_{\mathrm{P}}$ in the numerator but also because $6 \pi$ is changed to $3 \pi$ in the denominator.

In the present study, we found that the Dean (1978) model underestimated and the Knuston et al. (1982) model overestimated wave attenuation in the $S$. alterniflora marsh in Eastern Chongming. Hence, we introduced a combined drag coefficient associated with plants and bottom friction $\left(C_{\mathrm{C}}\right)$ into Eq. 2:

$A=\frac{C_{\mathrm{D}} C_{\mathrm{C}} D}{6 \pi S^{2} d}$

where $C_{\mathrm{C}}=2$ for the overall average water depth and $C_{\mathrm{C}}=$ 1.3-3.8 for changing water depth (i.e., $C_{\mathrm{C}}=2 d_{\mathrm{a}} / d$, where $d_{\mathrm{a}}$ is the overall average water depth (average of all the tides and transects) and $d$ is the specific single tide- and transect-averaged water depth; $C_{\mathrm{C}}=1.3$ for the highest $d$ 
and $C_{\mathrm{C}}=3.8$ for the lowest $d$ of the present study). $C_{\mathrm{C}}=2$ and $C_{\mathrm{C}}=1.3-3.8$ were empirical drag coefficients fittest to the $S$. alterniflora marsh in Eastern Chongming. Considering that the basal stem diameter is significantly larger than the terminal stem diameter, we employed the average stem diameter for the water depth in our calculation. Similarly, we used the depth-averaged spacing of grass stems because the stem density decreases from the ground level to the canopy (Fig. 2). We also used the average water depth along the marsh transect; i.e., the average of the water depths at the seaward and landward sides of the marsh transect.

The root mean square error was used to quantify the average error between predicted and measured heights of transmitted waves, expressed as follows:

$R_{\mathrm{E}}=\left[\sum_{i=1}^{n} \frac{\left(H_{2 \mathrm{P} i}-H_{2 \mathrm{M} i}\right)^{2}}{n}\right]^{\frac{1}{2}}$

where $H_{2 \mathrm{P}}$ is the predicted height of the transmitted waves, $H_{2 \mathrm{M}}$ is the measured height of the transmitted waves, and $n$ is the number of runs.

\section{Results}

\section{Temporal and Spatial Changes in Wave Height}

The burst-based significant wave height ranged from 0.01 to $0.73 \mathrm{~m}$ (Fig. 3) and the tide-based maximum wave height ranged from 0.02 to $1.50 \mathrm{~m}$ (Table 1). At each site, the wave height tended to increase with water depth (Figs. 2 and 3). Along the transects, the wave height was almost always lower at the marsh site than at the mudflat site and decreased with distance from the outer marsh towards the inner marsh (Fig. 3). For example, the tide-averaged significant wave height was $30 \pm 12 \%$ lower at Site 4 than at Site 2, 27 $\pm 10 \%$ lower at Site 5 than at Site 4, and $58 \pm$ $15 \%$ lower at Site 6 than at Site 5 (Table 1). The wave height over the mudflat on the landward side of the marsh tussock (Site 9) tended to be lower than that on the seaward side (Site 7) but tended to be greater than that recorded over the marsh tussock (i.e., Site 8; Fig. 3e). Specifically, the wave height at mudflat Site 3 was almost equal to that in front of the marsh cape (Site 2) but was significantly greater than that over the parallel area of the marsh (i.e., Site 4; Fig. 3a).

\section{Relationship Between Wave Height and Water Depth}

There was a strong correlation between significant wave height and water depth (i.e., the correlation coefficients ranging from 0.825 to 0.991 ; Fig. 4). The relative significant wave height (ratio of wave height to water depth), ranged from $0.11 \pm 0.01$ to $0.44 \pm 0.07$. Along the measurement transect (Sites 1-6), the highest relative wave height was always recorded at Site 4 . Similarly, the relative wave height was higher within the vegetation tussock (Site 8) than around the vegetation tussock (Sites 7 and 9). In other words, relative wave height appeared to be maximal at the marsh front. From Sites 4 to 5, and to Site 6, the relative wave height significantly decreased, and the relative wave heights at both Sites 5 and 6 were lower than at the mudflat site.

\section{Influence of Winds on Wave Height}

Under comparable tide conditions, wave heights showed marked differences in response to wind conditions (Fig. 4d). For example, at Site 5, the relationship between wave height and water depth differed strongly between days due to differences in wind speed; the higher wind speed during Tide
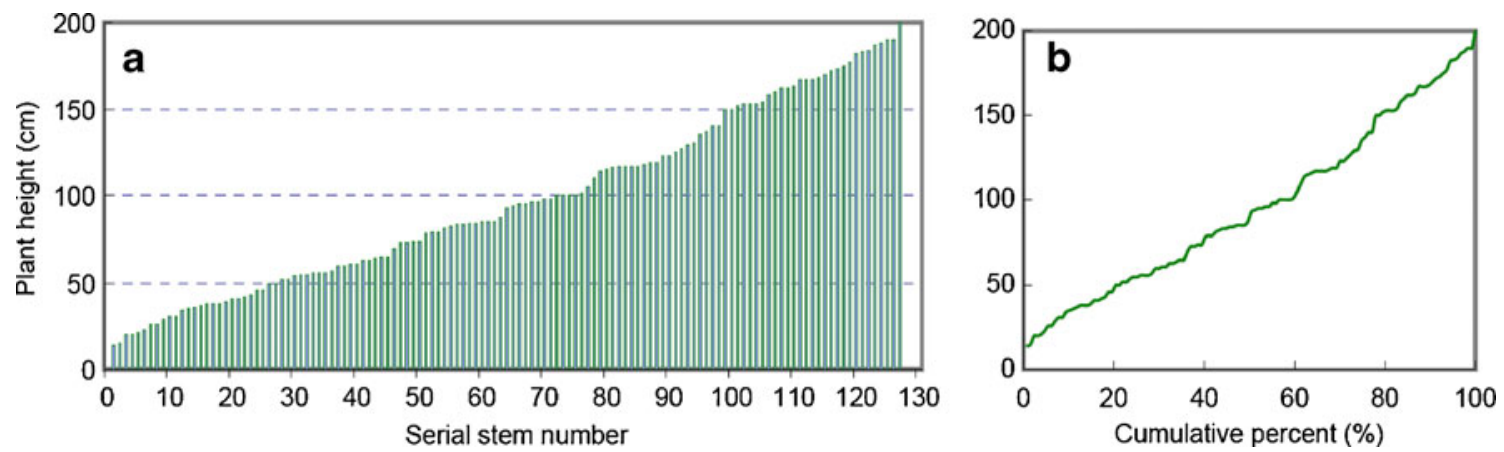

Fig. 2 Plant heights (a) and cumulative distribution of plant heights (b) of S. alterniflora in the study area (based on a $0.5 \times 0.5 \mathrm{~m}$ sampling plot). The total stem density of the sampled S. alterniflora of the present study was $508 \mathrm{stems} / \mathrm{m}^{2}$ (a). The plant heights of the present study ranged from 0.15 to $2.0 \mathrm{~m}$, with a mean height of $0.97 \mathrm{~m} .20 \%$ of the plants were lower than $0.5 \mathrm{~m} ; 39 \%$ of them were between 0.5 and $1.0 \mathrm{~m}$ in height; only $21 \%$ of them were taller than $1.5 \mathrm{~m}(\mathbf{b}) . \mathrm{In}$ other words, the stem density at the height of $1.0 \mathrm{~m}$ was only half of the stem density at the height of $0.5 \mathrm{~m}$ above sediment surface, and the stem density at the height of $1.5 \mathrm{~m}$ above sediment surface was only $26 \%$ of the stem density at the height of $0.5 \mathrm{~m}$ above sediment surface. Sprouts of less than $0.5 \mathrm{~m}$ in height accounted for $20 \%$ of the stems. The projected coverage was about $95 \%$ 
Fig. 3 Time series of burstbased water depth and significant wave height for sequential tidal cycles 1-4 (a), 5 and 6 (b), 7-9 (c), 10 and 11 (d), and 12 and 13 (e). The locations of wave-measuring sites are shown in Fig. 1d. Water depth was always based on records taken at the site with the lowest site number (i.e., closest to the water front), as indicated by the blue line in each panel
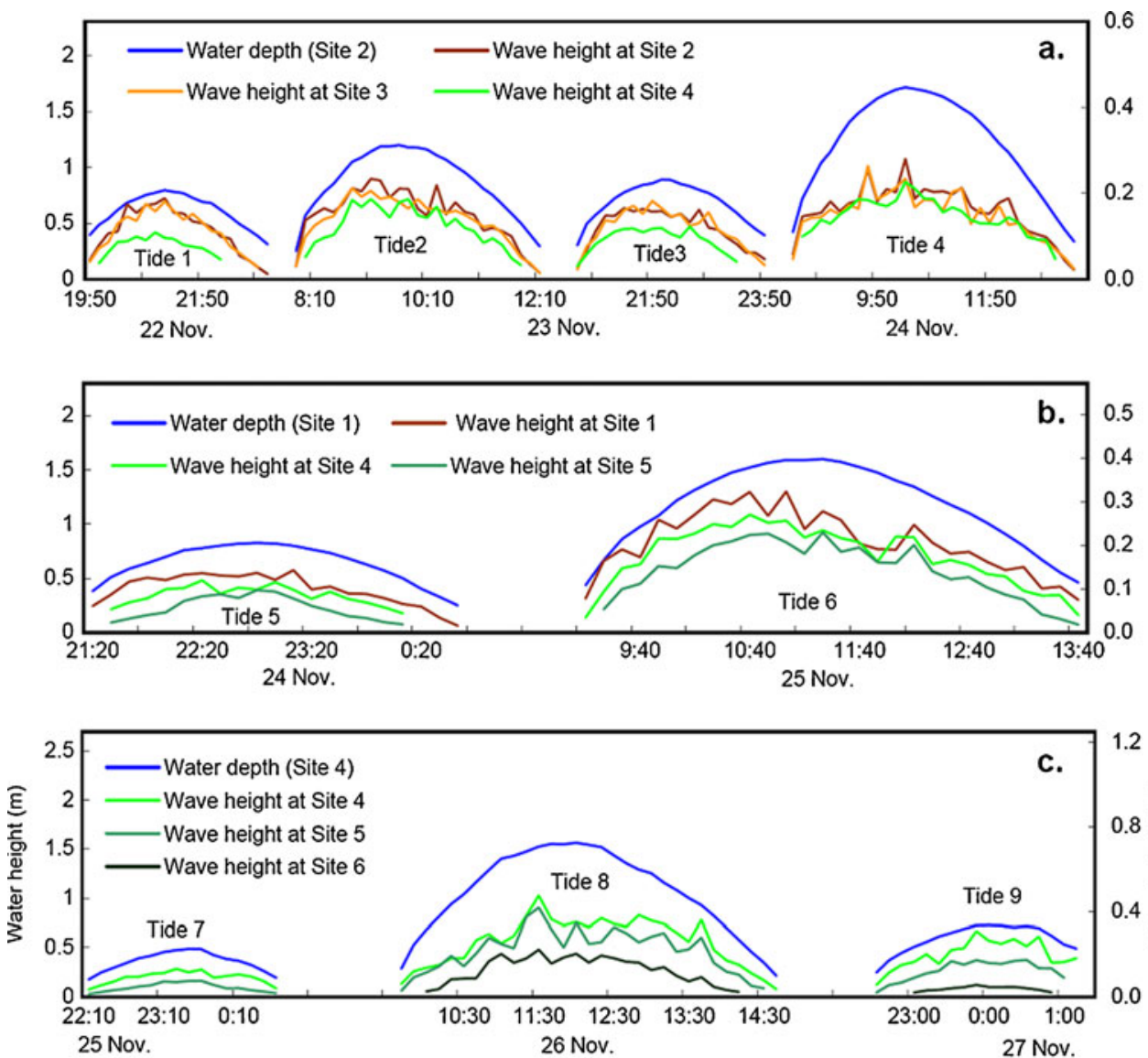

C.

1.2

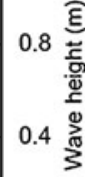
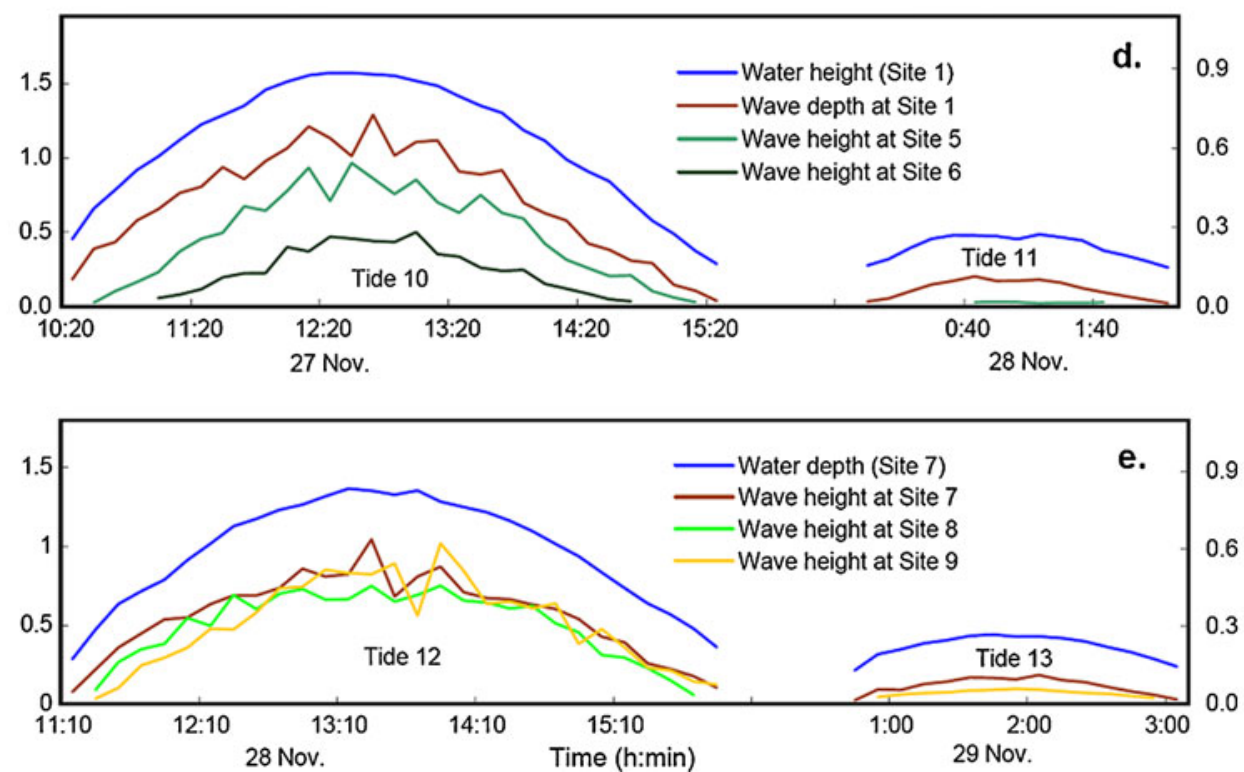

10 resulted in waves that were twice as high as on other days when wind speed was less (Fig. 5), for a given water depth.

Wave Attenuation Rate Across the Salt Marsh Vegetation

The wave attenuation rate, defined as the relative decrease in wave height/energy per unit distance, varied significantly in space and time $(1.3 \% / \mathrm{m}$ to $6.0 \% / \mathrm{m}$; Fig. 6$)$. Temporally, the wave attenuation rate tended to be greatest during low inundation levels (Table 1). This could be characterized by a close inverse-power correlation between the wave attenuation rate and relative water depth (the ratio of water depth to plant height); i.e., the lower the relative water depth, the more effective the wave attenuation (Fig. 6). For each 
Table 1 Tide-averaged total wave energy, significant wave height, tide-based maximum water depth, and maximum wave height during coinstantaneous submergence of tidal cycles

\begin{tabular}{|c|c|c|c|c|c|c|c|c|c|c|c|c|}
\hline \multirow[t]{2}{*}{ Tide } & \multicolumn{3}{|c|}{$\begin{array}{l}\text { Tide-averaged total wave } \\
\text { energy }\left(\mathrm{J} / \mathrm{m}^{2}\right)\end{array}$} & \multicolumn{3}{|c|}{$\begin{array}{l}\text { Tide-averaged significant } \\
\text { wave height }(\mathrm{m})\end{array}$} & \multicolumn{3}{|c|}{ Maximum wave height (m) } & \multicolumn{3}{|c|}{ Maximum water depth (m) } \\
\hline & $\begin{array}{l}\text { Mudflat } \\
\quad \text { (Site 2) }\end{array}$ & $\begin{array}{l}\text { Mudflat } \\
\text { (Site 3) }\end{array}$ & $\begin{array}{l}\text { Marsh } \\
\quad \text { (Site 4) }\end{array}$ & $\begin{array}{l}\text { Mudflat } \\
\quad \text { (Site 2) }\end{array}$ & $\begin{array}{l}\text { Mudflat } \\
\text { (Site 3) }\end{array}$ & $\begin{array}{l}\text { Marsh } \\
\quad \text { (Site 4) }\end{array}$ & $\begin{array}{l}\text { Mudflat } \\
\quad \text { (Site 2) }\end{array}$ & $\begin{array}{l}\text { Mudflat } \\
\text { (Site 3) }\end{array}$ & $\begin{array}{l}\text { Marsh } \\
\quad \text { (Site 4) }\end{array}$ & $\begin{array}{l}\text { Mudflat } \\
\quad \text { (Site 2) }\end{array}$ & $\begin{array}{l}\text { Mudflat } \\
\text { (Site 3) }\end{array}$ & $\begin{array}{l}\text { Marsh } \\
\quad(\text { Site 4) }\end{array}$ \\
\hline $\begin{array}{c}\text { Tide } \\
1\end{array}$ & 22.2 & 19.6 & 4.9 & 0.144 & 0.136 & 0.079 & 0.347 & 0.343 & 0.181 & 0.80 & 0.76 & 0.67 \\
\hline $\begin{array}{l}\text { Tide } \\
2\end{array}$ & 27.6 & 23.6 & 16.9 & 0.168 & 0.151 & 0.125 & 0.493 & 0.327 & 0.348 & 1.20 & 1.16 & 1.07 \\
\hline $\begin{array}{c}\text { Tide } \\
3\end{array}$ & 20.1 & 18.9 & 8.1 & 0.132 & 0.130 & 0.091 & 0.277 & 0.299 & 0.189 & 0.89 & 0.85 & 0.77 \\
\hline \multirow{2}{*}{$\begin{array}{c}\text { Tide } \\
4\end{array}$} & 26.9 & 25.1 & 23.3 & 0.176 & 0.159 & 0.147 & 0.507 & 0.453 & 0.315 & 1.71 & 1.67 & 1.56 \\
\hline & $\begin{array}{l}\text { Mudflat } \\
\text { (Site 1) }\end{array}$ & $\begin{array}{l}\text { Marsh } \\
\quad \text { (Site 4) }\end{array}$ & $\begin{array}{l}\text { Marsh } \\
\quad \text { (Site 5) }\end{array}$ & $\begin{array}{l}\text { Mudflat } \\
\quad \text { (Site 1) }\end{array}$ & $\begin{array}{l}\text { Marsh } \\
\quad \text { (Site 4) }\end{array}$ & $\begin{array}{l}\text { Marsh } \\
\quad \text { (Site 5) }\end{array}$ & $\begin{array}{l}\text { Mudflat } \\
\quad \text { (Site 1) }\end{array}$ & $\begin{array}{l}\text { Marsh } \\
\quad \text { (Site 4) }\end{array}$ & $\begin{array}{l}\text { Marsh } \\
\quad \text { (Site 5) }\end{array}$ & $\begin{array}{l}\text { Mudflat } \\
\quad \text { (Site 1) }\end{array}$ & $\begin{array}{l}\text { Marsh } \\
\quad \text { (Site 4) }\end{array}$ & $\begin{array}{l}\text { Marsh } \\
\quad(\text { Site 5) }\end{array}$ \\
\hline $\begin{array}{l}\text { Tide } \\
5\end{array}$ & 14.0 & 7.46 & 4.48 & 0.112 & 0.085 & 0.056 & 0.267 & 0.243 & 0.174 & 0.83 & 0.62 & 0.62 \\
\hline \multirow{2}{*}{$\begin{array}{l}\text { Tide } \\
6\end{array}$} & 46.1 & 34.5 & 23.6 & 0.212 & 0.179 & 0.143 & 0.591 & 0.743 & 0.497 & 1.60 & 1.39 & 1.39 \\
\hline & $\begin{array}{l}\text { Marsh } \\
\quad \text { (Site 4) }\end{array}$ & $\begin{array}{l}\text { Marsh } \\
\quad \text { (Site 5) }\end{array}$ & $\begin{array}{l}\text { Marsh } \\
\quad \text { (Site 6) }\end{array}$ & $\begin{array}{l}\text { Marsh } \\
\quad \text { (Site 4) }\end{array}$ & $\begin{array}{l}\text { Marsh } \\
\quad \text { (Site 5) }\end{array}$ & $\begin{array}{l}\text { Marsh } \\
\quad \text { (Site 6) }\end{array}$ & $\begin{array}{l}\text { Marsh } \\
\quad \text { (Site 4) }\end{array}$ & $\begin{array}{l}\text { Marsh } \\
\quad \text { (Site 5) }\end{array}$ & $\begin{array}{l}\text { Marsh } \\
\quad \text { (Site 6) }\end{array}$ & $\begin{array}{l}\text { Marsh } \\
\quad \text { (Site 4) }\end{array}$ & $\begin{array}{l}\text { Marsh } \\
\quad \text { (Site 5) }\end{array}$ & $\begin{array}{l}\text { Marsh } \\
\quad \text { (Site 6) }\end{array}$ \\
\hline $\begin{array}{c}\text { Tide } \\
7\end{array}$ & 6.25 & 2.36 & - & 0.091 & 0.045 & - & 0.205 & 0.122 & - & 0.54 & 0.54 & - \\
\hline $\begin{array}{c}\text { Tide } \\
8\end{array}$ & 77.3 & 56.7 & 20.0 & 0.274 & 0.218 & 0.127 & 1.18 & 1.14 & 0.389 & 1.62 & 1.62 & 1.30 \\
\hline \multirow{2}{*}{$\begin{array}{c}\text { Tide } \\
9\end{array}$} & 52.6 & 23.1 & 1.03 & 0.228 & 0.146 & 0.038 & 0.771 & 0.466 & 0.063 & 0.78 & 0.78 & 0.47 \\
\hline & $\begin{array}{l}\text { Mudflat } \\
\quad \text { (Site 1) }\end{array}$ & $\begin{array}{l}\text { Marsh } \\
\quad \text { (Site 5) }\end{array}$ & $\begin{array}{l}\text { Marsh } \\
\quad \text { (Site 6) }\end{array}$ & $\begin{array}{l}\text { Mudflat } \\
\quad \text { (Site 1) }\end{array}$ & $\begin{array}{l}\text { Marsh } \\
\quad \text { (Site 5) }\end{array}$ & $\begin{array}{l}\text { Marsh } \\
\quad \text { (Site 6) }\end{array}$ & $\begin{array}{l}\text { Mudflat } \\
\quad \text { (Site 1) }\end{array}$ & $\begin{array}{l}\text { Marsh } \\
\quad \text { (Site 5) }\end{array}$ & $\begin{array}{l}\text { Marsh } \\
\quad \text { (Site 6) }\end{array}$ & $\begin{array}{l}\text { Mudflat } \\
\quad \text { (Site 1) }\end{array}$ & $\begin{array}{l}\text { Marsh } \\
\quad \text { (Site 5) }\end{array}$ & $\begin{array}{l}\text { Marsh } \\
\quad \text { (Site 6) }\end{array}$ \\
\hline $\begin{array}{r}\text { Tide } \\
10\end{array}$ & 230 & 117 & 28.5 & 0.482 & 0.330 & 0.144 & 1.50 & 1.45 & 0.571 & 1.57 & 1.34 & 1.05 \\
\hline \multirow{2}{*}{$\begin{array}{c}\text { Tide } \\
11\end{array}$} & 3.99 & 0.236 & - & 0.07 & 0.016 & - & 0.161 & 0.019 & - & 0.48 & 0.19 & - \\
\hline & $\begin{array}{l}\text { Mudflat } \\
\quad \text { (Site 7) }\end{array}$ & $\begin{array}{l}\text { Mudflat } \\
\quad \text { (Site 9) }\end{array}$ & $\begin{array}{l}\text { Marsh } \\
\quad(\text { Site 8) }\end{array}$ & $\begin{array}{l}\text { Mudflat } \\
\quad \text { (Site 7) }\end{array}$ & $\begin{array}{l}\text { Mudflat } \\
\text { (Site 9) }\end{array}$ & $\begin{array}{l}\text { Marsh } \\
\quad \text { (Site 8) }\end{array}$ & $\begin{array}{l}\text { Mudflat } \\
\quad \text { (Site 7) }\end{array}$ & $\begin{array}{l}\text { Mudflat } \\
\text { (Site 9) }\end{array}$ & $\begin{array}{l}\text { Marsh } \\
\quad \text { (Site 8) }\end{array}$ & $\begin{array}{l}\text { Mudflat } \\
\quad \text { (Site 7) }\end{array}$ & $\begin{array}{l}\text { Mudflat } \\
\quad \text { (Site 9) }\end{array}$ & $\begin{array}{l}\text { Marsh } \\
\quad(\text { Site 8) }\end{array}$ \\
\hline $\begin{array}{r}\text { Tide } \\
12\end{array}$ & 120 & 113 & 98.2 & 0.361 & 0.313 & 0.307 & 1.03 & 1.09 & 0.925 & 1.42 & 1.27 & 1.08 \\
\hline $\begin{array}{r}\text { Tide } \\
13\end{array}$ & 4.70 & 1.57 & - & 0.079 & 0.044 & - & 0.167 & 0.080 & - & 0.44 & 0.29 & - \\
\hline
\end{tabular}

The sites are shown in Fig. 1

- the wave sensor was not submerged or the water was too shallow for effective wave recording

interval along the transect from Sites 2-6 (i.e., Sites 2-4, 4 5 , and 5-6), the same inverse-power relation pattern was observed, albeit at a lower level. The tide-averaged significant wave height (and also wave energy) exponentially decreased with landward distance from the marsh edge (Fig. 7), which suggests the rate of wave attenuation decreased as waves propagated through the marsh. Figure 5 also shows that the wave attenuation rate tended to be higher in shallower water, because the coefficient $K$ in $H_{x}=A e^{-K x}$ is greater at lower water depth. Nevertheless, for the tidal maximum wave height, the exponential landward decrease in wave attenuation was often less well defined, probably due to a shoaling effect and wave breaking, which are significant when wave height is similar to water depth (Table 1).
Comparison of Predicted and Measured Wave Attenuation

In the S. alterniflora salt marsh of Eastern Chongming, the predicted height of transmitted waves, based on the Dean (1978) model, tended to be overestimated; i.e., wave attenuation across the marsh was underestimated by the model. In contrast, the Knuston et al. (1982) model overestimated wave attenuation in the $S$. alterniflora salt marsh of Eastern Chongming. When a combined drag coefficient $\left(C_{\mathrm{C}}=2\right)$ was employed in Eq. 4, predicted heights of the transmitted waves were typically closely correlated with those measured in the field, with a correlation coefficient $(r)$ of 0.95 and a root mean square error of $1.9 \mathrm{~cm}$ (Fig. 8a). However, in this case (where $C_{\mathrm{C}}=2$ ), the 

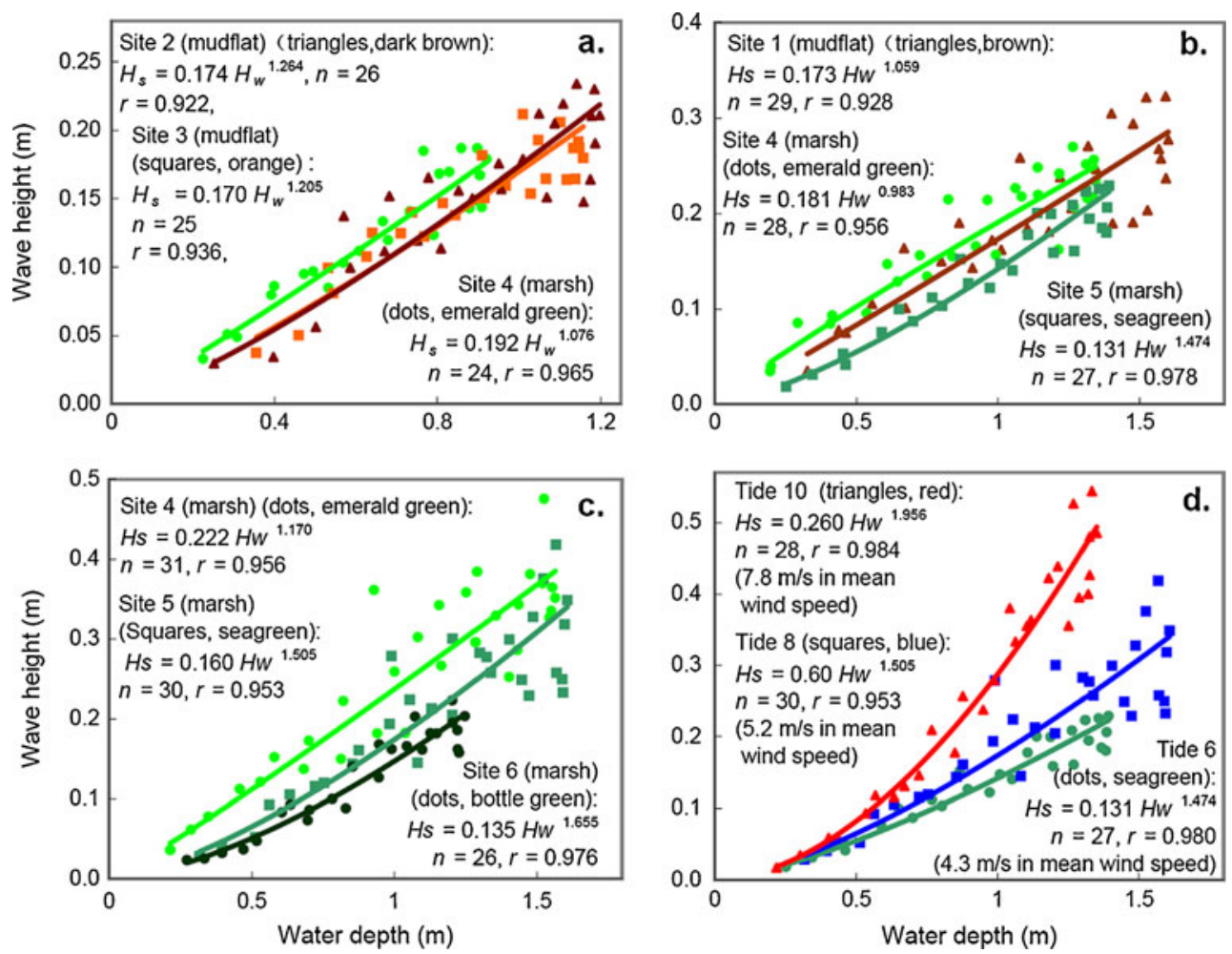

Fig. 4 Regression relationships between burst-based significant wave height $(H s)$ and water depth $(H w)$ over various tidal cycles (all significance levels are $P<0.0001$ ). The first three panels focus on the effect of location, whereas (d) shows the effect of wind speed, comparing (a) Sites 2, 3, and 4 during Tide 2; (b) Sites 1, 4, and 5 during Tide 6; (c) Sites 4, 5 and 6 during Tide 8; and (d) Tides 6 (slowest wind), 8 (medium wind), and 10 (strongest winds) at Site 5.

specific predicted wave attenuation tended to be lower than that measured for shallow water depths and small wave heights and higher than that measured for deeper water and large wave heights (Table 4; Fig. 8a). For example, wave attenuation predicted using the model for marsh Sites 5 and 6 was $26 \%$ higher than attenuation measured in the field during Tide 8 , when water depth $(106 \mathrm{~cm})$ was higher than

The hourly mean wind speed (wind direction) ranged from 4.6 to $5.5 \mathrm{~m} / \mathrm{s}\left(133-144^{\circ}\right)$ for Tide $2,3.8$ to $4.8 \mathrm{~m} / \mathrm{s}\left(129-134^{\circ}\right)$ for tide 6 , 1.1 to $9.4 \mathrm{~m} / \mathrm{s}\left(353-74^{\circ}\right)$ for Tide 8 , and 7.3 to $8.4 \mathrm{~m} / \mathrm{s}\left(357-2^{\circ}\right)$ for Tide 10 . Hourly maximum wind speed ranged from 4.7 to $14.8 \mathrm{~m} / \mathrm{s}$ for Tide 8 , and 11.1 to $13.1 \mathrm{~m} / \mathrm{s}$ for Tide 10 (wind speed and direction data are shown in Fig. 5). $n$ data number; $r$ correlation coefficient

the average (Tables 2 and 4). In contrast, during Tide 9, when the water depth $(52 \mathrm{~cm})$ was lower than the average, predicted wave height attenuation was $20 \%$ lower than that measured in the field (Tables 4 and 2). Overall, the relative difference between predicted and measured wave attenuation ranged from $-44 \%$ to $60 \%$ (Table 2 ), and there was a significant correlation between this difference and water

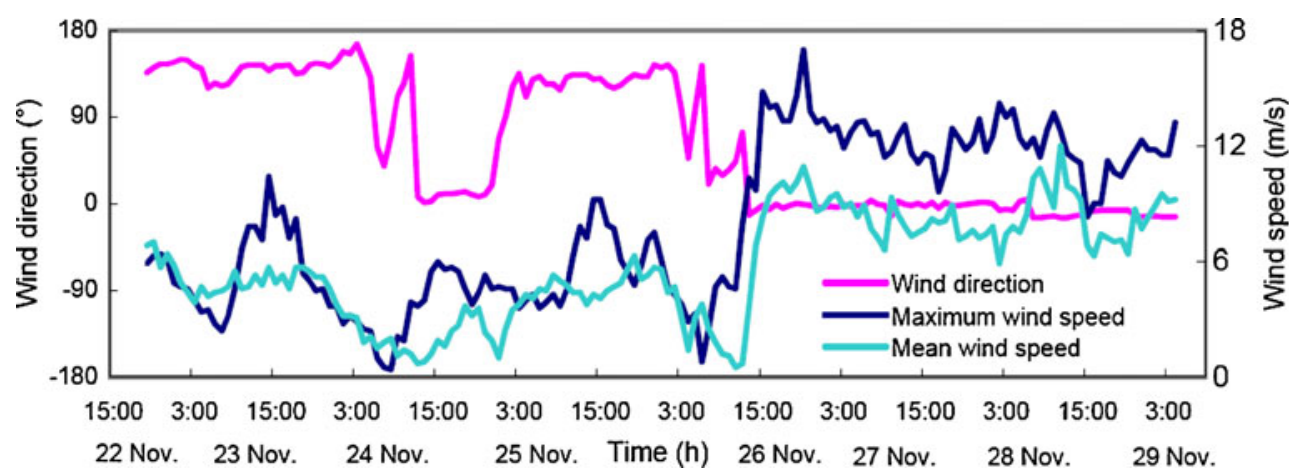

Fig. 5 Hourly wind speed and direction during the period of wave measurements. The mean wind speed was recorded at a marine gauging station, whereas the maximum wind speed was recorded at an inland gauging station. The wind direction corresponds to the mean

speed. Inverse values of wind direction represent the difference between the actual wind direction and $360^{\circ}$. For example, $-10^{\circ}$ in the ure represents $350^{\circ}$ in actual wind direction 


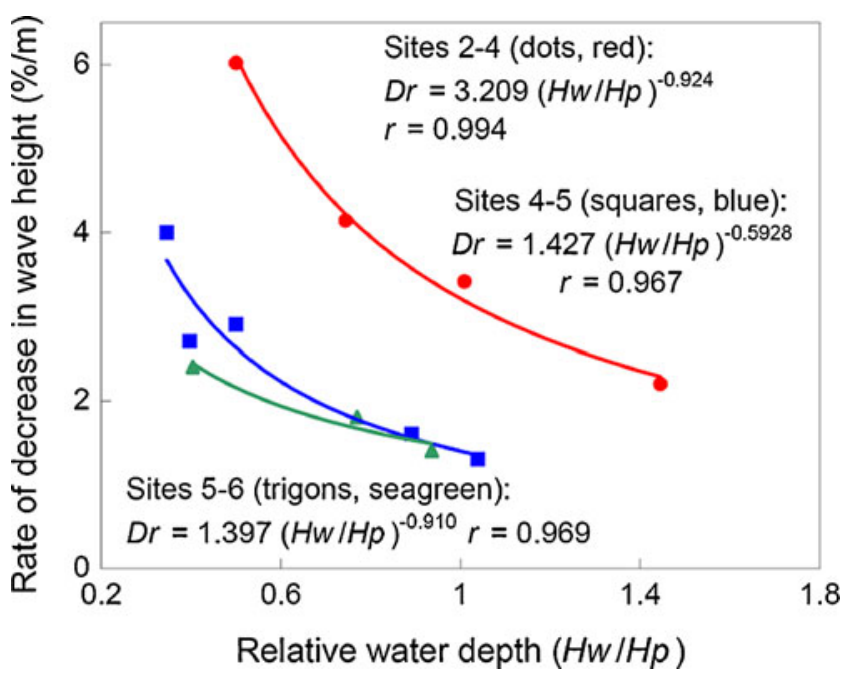

Fig. 6 Regression relationship between tide-averaged decreasing rate of significant wave height and relative water depth (defined as the ratio of water depth to significant plant height). $\mathrm{Dr}$ tide-averaged rate of decrease in wave height $(\% / \mathrm{m}) ; H w$ water depth at high tide $(\mathrm{m})$; $H p$ average height of the tallest $33 \%$ of plant stems $(\mathrm{m}) ; r$ correlation coefficient. Data are taken from Table 1 (Sites 2-4 during Tides 1-4, Sites 4 and 5 during Tides 5-9, and Sites 5 and 6 during Tides 8-10)

depth (Fig. 9). The empirical equation suggests (Fig. 9) that predicted wave attenuation tended to be higher (lower) than the measured attenuation when the water depth was greater

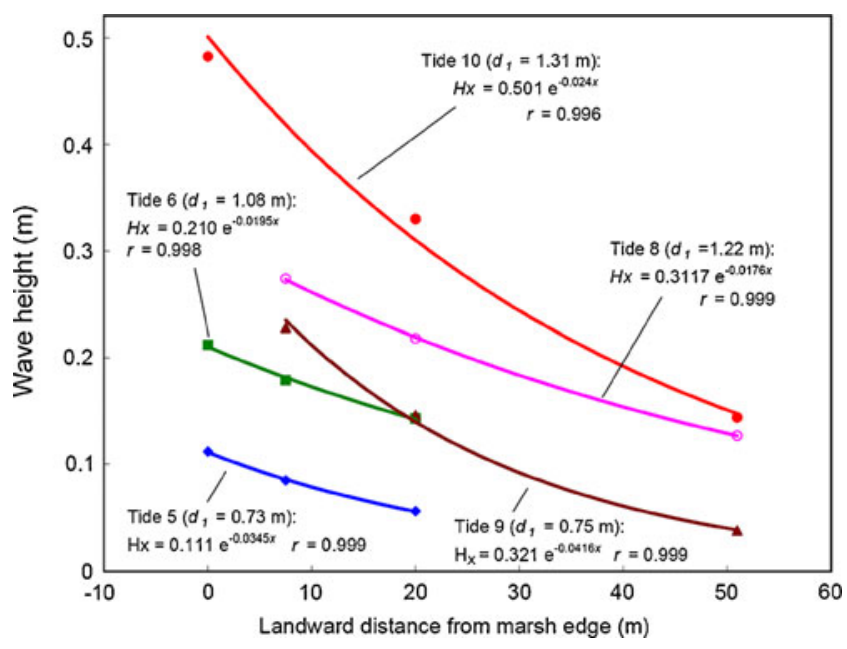

Fig. 7 Exponential decrease in tide-averaged significant wave height across the salt marsh. For Tides 5, 6, and 10, the measured water depths and wave heights at Site $1(7.5 \mathrm{~m}$ seaward from the marsh edge and $1 \mathrm{~cm}$ lower in elevation than at Site 2 at the marsh edge) were utilized as the initial conditions of wave height and water depth. The wave decay across this $7.5 \mathrm{~m}$ mudflat was considered by referring to a previously determined wave attenuation rate $(0.006 \% / \mathrm{m})$ over a mudflat $2 \mathrm{~km}$ north of the present study site (Yang et al. 2008). The loss of wave height across the $7.5 \mathrm{~m}$ mudflat was calculated to be $<0.5 \%$. $d_{l}$ represents initial water depth. $d_{l}$ initial water depth (at the seaward of the transect); $x$ landward distance from the marsh edge; $H x$ wave height at $x ; r$ correlation coefficient (smaller) than $75 \mathrm{~cm}$. When the drag coefficient $C_{\mathrm{C}}$ in the model was changed from 2 to $1.3-3.8$ (according to relative water depth), the root mean square error between predicted and measured heights of transmitted waves was reduced to $1.1 \mathrm{~cm}(r=0.98)$ (Fig. 8b) and the range of relative difference decreased to $-28 \%$ to $25 \%$ (Table 2). For both $C_{\mathrm{C}}=2$ and $C_{\mathrm{C}}=1.3-3.8$, the predicted and measured heights of transmitted waves were equal $(11 \mathrm{~cm})$ (Table 3$)$ and the relative difference between predicted and measured wave attenuations was on average less than $\pm 3 \%$ (Table 2). Nevertheless, when the change in water depth was considered in the drag coefficient (i.e., $C_{\mathrm{C}}=1.3-3.8$ ), the specific predicted wave attenuation was closer to that measured in the field, and the correlation between the relative difference between predicted and measured wave attenuation and water depth became insignificant.

\section{Comparison of Wave Attenuation Predictions across Sites}

Although transmitted wave heights predicted using the Knuston et al. (1982) model (Eq. 3, where $C_{\mathrm{P}}=5$ ) and data derived for the $S$. alterniflora salt marshes of Chesapeake Bay were either higher or lower than those measured in the field (Table 4), the average predicted $(5.7 \mathrm{~cm})$ and measured $(5.3 \mathrm{~cm})$ transmitted wave heights were very similar (Table 3). Using the newly revised Dean (1978) model (Eq. 4, where $C_{\mathrm{C}}=2$ ) to predict the transmitted wave heights gave significantly larger values than those measured in the salt marshes of Chesapeake Bay, indicating that the Knuston et al. (1982) model performed better for this site. However, the Knuston et al. (1982) model underestimated the transmitted wave heights (i.e., overestimated wave attenuation) in the Eastern Chongming salt marsh (Tables 4 and 3). Overall, this comparison indicates that selecting a proper drag coefficient is highly important for predicting wave attenuation, and will be discussed in detail in section Predicting Wave Attenuation in Salt Marshes.

\section{Discussion}

Cross-Shore and Temporal Changes in Wave Attenuation Rate in Salt Marsh

The significant difference between wave attenuation rates across marsh stretches with different distance from the marsh edge (Fig. 6) is in line with observations made in flume studies (Bouma et al. 2005b, 2010). An earlier field study also reported that the most rapid attenuation of waves occurs over the most seaward $10 \mathrm{~m}$ of a salt marsh (Möller and Spencer 2002). The present study clearly showed temporal changes in wave attenuation due to the effect of 


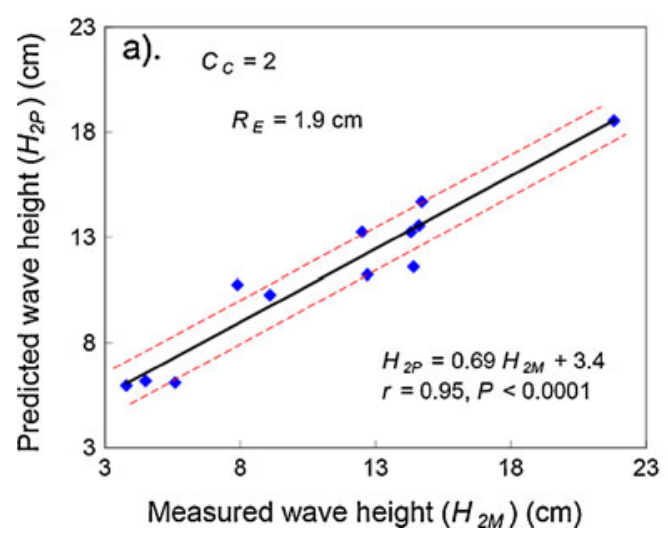

Fig. 8 Correlation between predicted and measured heights of transmitted waves, showing a predicted values calculated based on our revised Dean (1978) model (adding a combined drag coefficient $C_{\mathrm{C}}=2$ to Eq. 2), and $\mathbf{b}$ predicted values calculated by changing the

water depth relative to plant height. This finding is probably not only due to bottom friction (i.e., the lower the water depth, the stronger the interaction between waves and the marsh bottom), but mainly due to a higher plantstem density at lower levels in the vegetation. For example, the stem density at $0.5 \mathrm{~m}$ is four times higher than at $1.5 \mathrm{~m}$ above the sediment surface (Fig. 2). Consequently, the loss of wave energy due to vegetation friction increases with decreasing water depth. Thus, the present results confirm earlier observations showing that water depth is an

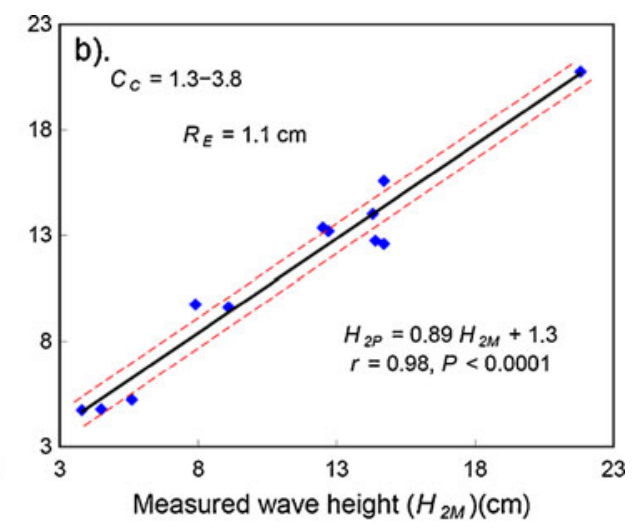

drag coefficient in our revised Dean (1978) model from 2 to $1.3-3.8$, according to the relative water depth (Table 2). $H_{2 M}$ : measured transmitted wave height; $H_{2 P}$ : predicted transmitted wave height; $R_{E}$ root mean square error; $r$ correlation coefficient; $P$ significance level

important factor determining wave attenuation in marshes (e.g., Möller et al. 1999).

\section{Causes of Differences in Wave Attenuation between Salt} Marsh and Unvegetated Tidal Flat

Although we did not study wave attenuation across the exposed mudflat in great detail, an earlier study at a site located $2 \mathrm{~km}$ north of the present site showed an attenuation rate of significant wave height of $0.06 \% / \mathrm{m}$ over a $185 \mathrm{~m}$

Table 2 Comparison of predicted and measured reductions of wave height in the salt marsh at Eastern Chongming

\begin{tabular}{|c|c|c|c|c|c|c|c|c|c|c|}
\hline Tide & Marsh stretch & $L(\mathrm{~cm})$ & $d(\mathrm{~cm})$ & $H_{1}(\mathrm{~cm})$ & $C_{C}(\mathrm{I}=1 ; \mathrm{II}=75 \mathrm{~cm} / d)$ & $D(\mathrm{~cm})$ & $S(\mathrm{~cm})$ & $1-H_{2 M} / H_{1}(\%)$ & $1-H_{2 P} / H_{1}(\%) \mathrm{I}(\mathrm{II})$ & $R_{d}(\%) \mathrm{I}(\mathrm{II})$ \\
\hline Tide 1 & Site $2-4$ & 750 & 53 & 14.4 & $1(1.42)$ & 0.36 & 4.4 & 45 & $25(32)$ & $-44(-28)$ \\
\hline Tide 2 & Site $2-4$ & 750 & 78 & 16.8 & $1(0.96)$ & 0.39 & 5.8 & 26 & $21(20)$ & $-19(-21)$ \\
\hline Tide 3 & Site $2-4$ & 750 & 57 & 13.2 & $1(1.32)$ & 0.37 & 4.8 & 31 & $22(27)$ & $-29(-12)$ \\
\hline Tide 4 & Site $2-4$ & 750 & 114 & 17.6 & $1(0.66)$ & 0.43 & 4.8 & 16 & 17 (12) & $6(-28)$ \\
\hline Tide 5 & Site $4-5$ & 1250 & 47 & 8.5 & $1(1.60)$ & 0.36 & 4.3 & 34 & $26(38)$ & $-24(13)$ \\
\hline Tide 6 & Site 4-5 & 1250 & 95 & 17.9 & $1(0.79)$ & 0.41 & 5.0 & 20 & $32(22)$ & $60(8.6)$ \\
\hline Tide 7 & Site 4-5 & 1250 & 39 & 9.1 & $1(1.92)$ & 0.35 & 4.1 & 51 & $32(47)$ & $-37(-6.9)$ \\
\hline Tide 8 & Site 4-5 & 1250 & 112 & 27.4 & $1(0.67)$ & 0.43 & 4.6 & 20 & $32(24)$ & $60(21)$ \\
\hline Tide 9 & Site 4-5 & 1250 & 63 & 22.8 & $1(1.19)$ & 0.37 & 4.3 & 36 & $41(45)$ & $14(25)$ \\
\hline Tide 8 & Site 5-6 & 3100 & 106 & 22.9 & $1(0.71)$ & 0.42 & 5.4 & 42 & $51(42)$ & $26(0.9)$ \\
\hline Tide 9 & Site 5-6 & 3100 & 52 & 14.6 & $1(1.44)$ & 0.36 & 4.4 & 74 & $59(68)$ & $-20(-8.7)$ \\
\hline Tide 10 & Site 5-6 & 3100 & 87 & 33.0 & $1(0.86)$ & 0.40 & 5.1 & 56 & $65(61)$ & $16(9.7)$ \\
\hline Average & & 1550 & 75 & 18 & $1(1.13)$ & 0.39 & 4.8 & 38 & $35(37)$ & $0.75(-2.3)$ \\
\hline Standard & deviation & 960 & 27 & 7.3 & $0(0.41)$ & 0.03 & 0.05 & 17 & $16(17)$ & 38 (18) \\
\hline
\end{tabular}

$L$ length of the stand of $S$. alterniflora from seaward to landward through which waves propagate; $d$ average water depth of the marsh stretch (average of the water depths at seaward and landward); $H_{1}$ measured incident wave height (significant wave height at seaward); $C_{C}$ drag coefficient ( $\mathrm{I}=2.0 ; \mathrm{II}=2 \times 75 \mathrm{~cm} /$ day, where $75 \mathrm{~cm}$ [or $22 \mathrm{~cm}$ below the average plant height] was the average water depth of the marsh transect for all the measured tides, assumed to be around the average stem length); $D$ average stem diameter (space and depth-averaged); $S$ average spacing of stems (assumed to be on square centers, based on depth-averaged stem density); $H_{2 m}$ measured transmitted wave height at the landward side of the marsh stretch; $H_{2 p}$ predicted transmitted wave height based on our revised Dean (1978) model (Eq. 4); $1-H_{2 m} / H_{1}$ measured relative reduction of wave height; $1-H_{2 p} / H$ predicted relative reduction of wave height; $R_{d}$ relative difference between predicted and measured reductions of wave height $\left.=\left[\left(1-H_{2 \mathrm{p}} / H_{1}\right)-\left(1-H_{2 \mathrm{~m}} / H_{1}\right)\right] /\left(1-H_{2 \mathrm{~m}} / H_{1}\right)\right)$ 


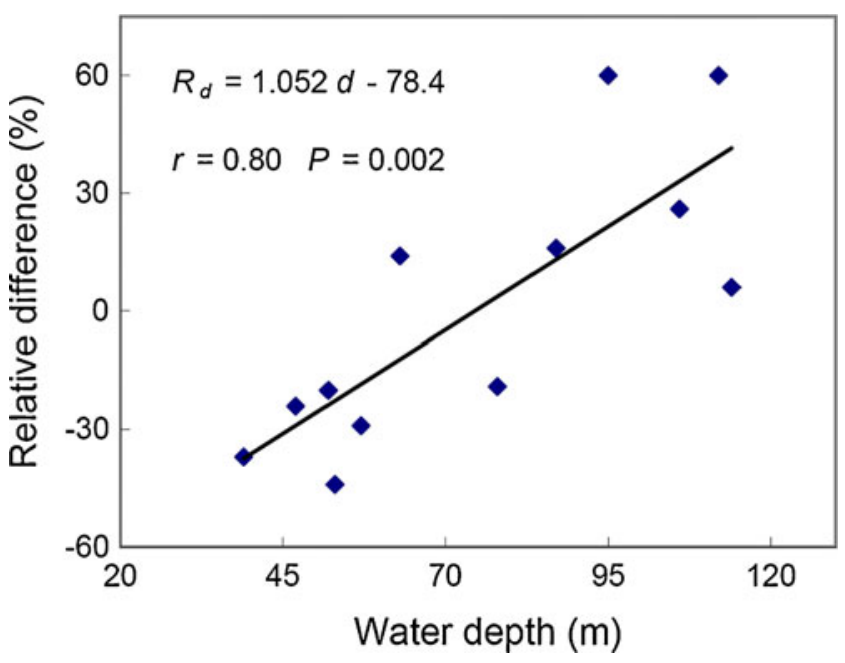

Fig. 9 Regression relationship between relative difference between predicted and measured reductions of wave height $(R d)$ and average water depth of the marsh stretch through which waves propagate $(d)$, based on the data in Table 2. $r$ correlation coefficient; $P$ significance level

transect (Yang et al. 2008). As suggested in Table 1, the wave attenuation rate over the S. alteniflora marsh at the present study site was 1 to 2 magnitudes higher than that on the adjacent mudflat. Although significant differences in wave attenuation between salt marsh and unvegetated areas have been well addressed (e.g., Möller et al. 1996; Yang 1998; Möller and Spencer 2002), little is known about how much of the difference is attributed to the presence of vegetation. Wave attenuation is sensitive to changes in elevation gradient (Kurian and Baba 1987). The average elevation gradient of the marsh transect (including the cliff at Site 2) was $12 \%$ (caption to Fig. 1), which is 10 times higher than that of the mudflat (Yang et al. 2008). In other words, the higher wave attenuation rate over the marsh transect (relative to the mudflat) is due to both the presence of marsh vegetation and the increase in marsh elevation gradient. Assuming that wave attenuation due to shoaling effects $(Y)$ is proportional to the bottom slope $(X)$ (i.e., $Y=$ $A X^{K}$ with $A$ and $K$ being coefficients), we would expect $K<$ 1 (i.e., less than linear) because bottom surface roughness (which is related to sediment grain size and ripples, etc.) would not increase linearly with slope. Indeed, wave decay is typically a nonlinear process. Therefore, wave attenuation due to shoaling would be significantly less than $0.6 \%$ / $\mathrm{m}$ in the present study (i.e., 10 times higher than that over the adjacent mudflat, considering the marsh elevation gradient is 10 times higher than the gradient of the adjacent mudflat), although it would be larger than $0.06 \% / \mathrm{m}$ (the wave attenuation rate over the adjacent mudflat). That is, less than $26 \%(0.6 \% / \mathrm{m})$ of the observed wave attenuation across the marsh transect $(2.34 \% / \mathrm{m}$ on average) could be attributed to shoaling effects, or more than $74 \%\left(2.34 \% / \mathrm{m}^{-}\right.$ $0.6 \% / \mathrm{m}=1.74 \% / \mathrm{m}$ ) of the observed wave attenuation across the marsh transect should be attributed to presence of vegetation. This also suggests that more than $76 \%(1.74 \% /$ $\mathrm{m}$ ) of the increase in wave attenuation across the salt marsh (relative to the mudflat) $(2.34 \% / \mathrm{m}-0.06 \% / \mathrm{m}=2.28 \% / \mathrm{m})$ should be attributed to presence of vegetation. We estimate that more than $80 \%$ of the increase in wave attenuation across the salt marsh (relative to the mudflat) was attributed to vegetation friction.

\section{Marsh Distance Required for Wave Elimination} in S. alterniflora Marsh

In an $S$. alterniflora marsh in the USA, wave height decreased by $71 \%$ over a distance of $20 \mathrm{~m}$ (Frey and Basan 1985). In Chesapeake Bay, Knuston et al. (1982) found that waves lost all their energy over a marsh distance of $30 \mathrm{~m}$. In the present study, we found that the tide-averaged significant wave height had decreased by $30 \%$ across the first $7.5 \mathrm{~m}$ of marsh, by $51 \%$ across the first $20 \mathrm{~m}$ of marsh, and by $79 \%$ across the first $51 \mathrm{~m}$ of marsh. Data in Fig. 6 give the regression relationship $A_{\mathrm{swh}}(\%)=10.96 D^{0.505},(r=$ 0.999), where $A_{\mathrm{swh}}=$ the attenuation of significant wave height; $D=$ the cross-shore distance (m) from the marsh edge; and $r=$ correlation coefficient. Extrapolating this correlation, the mean significant wave height is predicted to be completely eliminated over a distance of $80 \mathrm{~m}$ from the marsh edge. Assuming that $>80 \%$ of the wave attenuation was due to vegetation friction (Causes of Differences in Wave Attenuation Between Salt Marsh and Unvegetated Tidal Flat), the transmission distance of the

Table 3 Comparison between Eastern Chongming and Chesapeake Bay

\begin{tabular}{llllllllll}
\hline Locations & Number of runs & $S_{L}(\%)$ & $d(\mathrm{~cm})$ & $d_{l}(\mathrm{~cm})$ & $L(\mathrm{~cm})$ & $H_{l}(\mathrm{~cm})$ & $H_{2 M}(\mathrm{~cm})$ & $H_{2 P-\mathrm{Knutson}}(\mathrm{cm})$ & $H_{2 P-\mathrm{Dean}}(\mathrm{cm})$ \\
\hline Chesapeake Bay & 31 & 4.4 & 45 & 22 & 1050 & 16 & 5.3 & 5.7 & 11 \\
Eastern Chongming & 12 & 1.2 & 75 & 66 & 1550 & 18 & 11 & 5.1 & 11 \\
\hline
\end{tabular}

Original data for each run are shown in Table 4

In terms of the average slope $\left(S_{L}\right)$ and water depth $(d)$ of marsh transects, water depth at landward sites $\left(d_{L}\right)$, length of the marsh transect $(L)$, incident wave height $\left(H_{1}\right)$, measured transmitted wave height $\left(H_{2 m}\right)$, predicted transmitted wave height $\left(H_{2 p}\right)$ based on the Knuston et al. (1982)

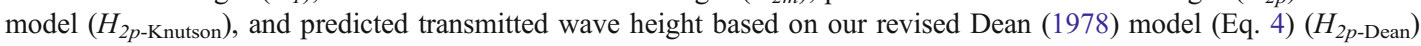


Table 4 Average spacing of stems $(S)$, stem diameter $(D)$, water depth $(d)$, length of the stand of marsh vegetation (from seaward to landward) through which waves propagate $(L)$, incident wave height $\left(H_{l}\right)$, measured transmitted wave height $\left(H_{2 m}\right)$, predicted transmitted

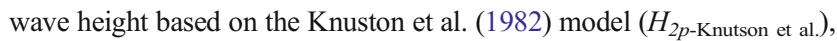
and predicted transmitted wave height based on our revised Dean (1978) model (Eq. 4, $\left.C_{C}=2\right)\left(H_{2 p \text {-Revised Dean }}\right)$

\begin{tabular}{|c|c|c|c|c|c|c|c|c|c|c|}
\hline Locations & & Runs & $\mathrm{S}(\mathrm{cm})$ & $\mathrm{D}(\mathrm{cm})$ & $\mathrm{d}(\mathrm{cm})$ & $\mathrm{L}(\mathrm{cm})$ & $\mathrm{H}_{1}(\mathrm{~cm})$ & $\mathrm{H}_{2 \mathrm{~m}}(\mathrm{~cm})$ & $\mathrm{H}_{2 \mathrm{p}-\text { Knutson et al. }}(\mathrm{cm})$ & $\mathrm{H}_{2 \mathrm{p} \text {-Revised Dean }}(\mathrm{cm})$ \\
\hline \multirow[t]{12}{*}{ Eastern Chongming } & Site $2-4$ & 1 & 4.8 & 0.36 & 53 & 750 & 14.4 & 7.9 & 5.3 & 10.8 \\
\hline & & 2 & 5.0 & 0.39 & 78 & 750 & 16.8 & 12.5 & 7.1 & 13.2 \\
\hline & & 3 & 4.9 & 0.37 & 57 & 750 & 13.2 & 9.1 & 5.4 & 10.2 \\
\hline & & 4 & 5.2 & 0.43 & 114 & 750 & 17.6 & 14.7 & 8.8 & 14.7 \\
\hline & Site $4-5$ & 5 & 4.7 & 0.36 & 47 & 1250 & 8.5 & 5.6 & 2.9 & 6.1 \\
\hline & & 6 & 5.4 & 0.41 & 95 & 1250 & 17.9 & 14.3 & 6.5 & 13.3 \\
\hline & & 7 & 4.8 & 0.35 & 39 & 1250 & 9.1 & 4.5 & 2.7 & 6.2 \\
\hline & & 8 & 5.4 & 0.43 & 112 & 1250 & 27.4 & 21.8 & 8.2 & 18.6 \\
\hline & & 9 & 5.0 & 0.37 & 63 & 1250 & 22.8 & 14.7 & 5.0 & 13.4 \\
\hline & Site $5-6$ & 8 & 5.4 & 0.42 & 106 & 3100 & 21.8 & 12.7 & 3.7 & 11.0 \\
\hline & & 9 & 4.8 & 0.36 & 52 & 3100 & 14.6 & 3.8 & 1.8 & 5.9 \\
\hline & & 10 & 5.2 & 0.4 & 87 & 3100 & 33.0 & 14.4 & 3.3 & 11.7 \\
\hline \multirow[t]{31}{*}{ Chesapeake Bay } & Wescoast 1 & 1 & 5.9 & 0.48 & 48 & 442 & 16 & 14 & 7.6 & 13.1 \\
\hline & & 2 & 5.9 & 0.48 & 54 & 442 & 16 & 14 & 8.1 & 13.4 \\
\hline & & 3 & 5.9 & 0.48 & 67 & 869 & 18 & 8 & 6.6 & 13.4 \\
\hline & & 4 & 5.9 & 0.48 & 77 & 869 & 17 & 8 & 7.0 & 13.2 \\
\hline & Wescoast 2 & 1 & 7.3 & 0.53 & 17 & 457 & 18 & 8 & 5.0 & 11.8 \\
\hline & & 2 & 7.3 & 0.53 & 25 & 457 & 16 & 9 & 6.2 & 12.2 \\
\hline & & 3 & 7.3 & 0.53 & 50 & 945 & 17 & 7 & 6.3 & 12.7 \\
\hline & & 4 & 7.3 & 0.53 & 56 & 945 & 21 & 10 & 7.3 & 15.3 \\
\hline & Wescoast 3 & 1 & 7.5 & 0.44 & 34 & 494 & 20 & 6 & 9.0 & 16.0 \\
\hline & & 2 & 7.5 & 0.44 & 28 & 494 & 14 & 2 & 6.8 & 11.6 \\
\hline & & 3 & 7.5 & 0.44 & 26 & 250 & 14 & 6 & 9.0 & 12.6 \\
\hline & & 4 & 7.5 & 0.44 & 20 & 250 & 12 & 2 & 7.4 & 10.7 \\
\hline & Wescoast 4 & 1 & 7.1 & 0.53 & 49 & 472 & 13 & 4 & 7.6 & 11.4 \\
\hline & & 2 & 7.1 & 0.53 & 52 & 472 & 14 & 6 & 8.2 & 12.3 \\
\hline & & 3 & 7.1 & 0.53 & 64 & 244 & 16 & 13 & 12.0 & 15.0 \\
\hline & & 4 & 7.1 & 0.53 & 49 & 244 & 17 & 14 & 11.6 & 15.5 \\
\hline & Kings Creek 1 & 1 & 5.8 & 0.48 & 61 & 2941 & 16 & 0 & 2.3 & 7.4 \\
\hline & & 2 & 5.8 & 0.48 & 63 & 2941 & 18 & 1 & 2.4 & 7.9 \\
\hline & & 3 & 5.8 & 0.48 & 49 & 1933 & 17 & 1 & 2.8 & 8.4 \\
\hline & & 4 & 5.8 & 0.48 & 46 & 1935 & 16 & 1 & 2.6 & 7.9 \\
\hline & & 5 & 5.8 & 0.48 & 46 & 869 & 15 & 3 & 4.7 & 10.5 \\
\hline & & 6 & 5.8 & 0.48 & 43 & 869 & 17 & 2 & 4.7 & 11.1 \\
\hline & Kings Creek 2 & 1 & 5.4 & 0.51 & 43 & 442 & 12 & 6 & 5.6 & 9.7 \\
\hline & & 2 & 5.4 & 0.51 & 42 & 1012 & 15 & 2 & 3.4 & 9.0 \\
\hline & & 3 & 5.4 & 0.51 & 47 & 2012 & 13 & 2 & 2.1 & 6.4 \\
\hline & & 4 & 5.4 & 0.51 & 46 & 2012 & 12 & 3 & 2.0 & 6.0 \\
\hline & & 5 & 5.4 & 0.51 & 41 & 1012 & 12 & 2 & 3.2 & 7.7 \\
\hline & & 6 & 5.4 & 0.51 & 44 & 442 & 12 & 6 & 5.7 & 9.8 \\
\hline & Kings Creek 3 & 1 & 6.3 & 0.46 & 34 & 954 & 21 & 1 & 4.5 & 12.1 \\
\hline & & 2 & 6.3 & 0.46 & 37 & 1966 & 23 & 1 & 2.7 & 9.1 \\
\hline & & 3 & 6.3 & 0.46 & 46 & 2987 & 20 & 2 & 2.2 & 7.6 \\
\hline
\end{tabular}

The data of $S, D, d, L, H_{1}$, and $H_{2 m}$ in Chesapeake Bay are after Knuston et al. (1982) 
waves would be $>400 \mathrm{~m}$ if there was no vegetation present. Based on the Dean (1978) model and our revised drag coefficient related to water depth (Table 2), we also predicted that the waves would lose $91 \%$ of their height and $99 \%$ of their energy when they propagate through the S. alterniflora marsh over a distance of $80 \mathrm{~m}$, assuming the average incident significant wave height $(0.27 \mathrm{~cm})$ and the average water depth $(1.01 \mathrm{~cm})$ at the low marsh edge (Site 2). Assuming the maximum wave height $(1.5 \mathrm{~m})$ and maximum water depth $(1.9 \mathrm{~m})$ observed at the low marsh edge, wave height would decrease to $0.11 \mathrm{~m}(7 \%)$ over the first $100 \mathrm{~m}$ of the marsh $(0.7 \mathrm{~m}$ in water depth at the landward limit). In other words, more than $99 \%$ of the wave energy would be lost over this distance.

The efficiency of wave attenuation by S. alterniflora in the present study is thus somewhat lower than that measured for the S. alterniflora marsh in the USA described above. This is probably caused by a greater water depth, larger incoming waves, and a lower elevation gradient at the Eastern Chongming coast compared with the USA coast. For example, in Chesapeake Bay, the mean and spring tidal ranges were 0.73 and $0.88 \mathrm{~m}$, the mean and maximum water depths at the low marsh edge were 0.67 and $0.95 \mathrm{~m}$ during spring tides, the mean and maximum incident wave heights at the low marsh edge were 0.16 and $0.23 \mathrm{~m}$, and the mean and maximum elevation gradient were $4.4 \%$ and $14 \%$, respectively (Knuston et al. 1982). In contrast, the spring tidal range at Eastern Chongming was up to $4 \mathrm{~m}$, the mean and maximum water depths at the low marsh edge were 1.01 and $1.90 \mathrm{~m}$, the mean and maximum incident wave heights at the low marsh edge were 0.27 and $1.50 \mathrm{~m}$, respectively, and the mean elevation gradient was $1.2 \%$. It is well known that lower water depths and incident wave heights increase the efficiency of wave attenuation by marsh vegetation (e.g., Knuston et al. 1982; Möller 2006). The marsh elevation gradient is important for wave attenuation because it determines the water depth at the landward edge of the marsh transect. In Chesapeake Bay, the width of marsh inundated by tides was usually less than $30 \mathrm{~m}$ (based on Table 2 in Knuston et al. 1982). In the present study, for the mean elevation gradient and mean water depth at the low marsh edge $(1.01 \mathrm{~m})$, the water depth would be only $5 \mathrm{~cm}$ at $80 \mathrm{~m}$ landward from the marsh edge.

\section{Difference in Wave Attenuation between S. Alterniflora and Other Marsh Species}

For a salt marsh comprising Limonium, Aster, Atriplex (0.25 m high), Salicornia $(<0.1 \mathrm{~m}$ high), and Spartina spp. $(<0.4 \mathrm{~m}$ high $)$ in North Norfolk, UK, a decrease in significant wave height was measured at a rate of $0.34 \%$ / $\mathrm{m}$ (Möller et al. 1999). A comparative wave attenuation rate $(0.54 \% / \mathrm{m})$ was found across a salt marsh in Essex, UK, formed of similar vegetation species (Möller and Spencer 2002). In the Yangtze Estuary, a significant wave height attenuation rate of $0.95 \% / \mathrm{m}$ was measured across a marsh formed of taller $(0.5 \mathrm{~m})$ native $S$. mariqueter vegetation (Yang et al. 2008). Comparatively, the present study recorded much higher wave attenuation rates across a marsh formed of the tall (up to $2 \mathrm{~m}$ high) introduced species S. alterniflora $(1.3 \% / \mathrm{m}$ to $6.0 \% / \mathrm{m})$. This is not surprising considering the importance of relative water depth for wave attenuation (Fig. 6). Flume studies have shown that in addition to vegetation height, shoot stiffness, and overall standing biomass are important in determining wave attenuation rates (Bouma et al. 2005a, 2010).

\section{Predicting Wave Attenuation in Salt Marshes}

The original Dean (1978) model underestimated wave attenuation across salt marshes both in Chesapeake Bay (Knuston et al. 1982) and in the Yangtze Estuary. This is because the model considers marsh vegetation as an array of smooth vertical cylinders. In fact, Dean did not use marsh plants in his laboratory experiments, and no field measurements were obtained (Knuston et al. 1982). However, the results of Knuston et al. (1982) and the present study prove that the Dean model is useful in predicting wave attenuation across salt marshes when a suitable drag coefficient is introduced. This drag coefficient is associated with plant characteristics as well as bottom features. For the salt marsh in Eastern Chongming, a drag coefficient of 2.0 on average in Eq. 4 was suitable for predicting wave attenuation. The significant difference in drag coefficients between Chesapeake Bay and Eastern Chongming is probably due to the steeper slope of the bottom and lower water depth at Chesapeake Bay marsh compared to the Eastern Chongming marsh (Table 3). It is well known that the bed friction encountered by waves in shallow waters is proportional to elevation gradient and is inversely proportional to water depth (Kurian and Baba 1987).

Although the predicted wave attenuation based on our revised Dean (1978) model (Eq. 4, $C_{\mathrm{C}}=2$ ) was, on average, in agreement with that measured in Eastern Chongming, this model tended to underestimate wave attenuation in shallower water and to overestimate wave attenuation in deeper water (Fig. 9). This was also true for the Knuston et al. (1982) model (Eq. 3) used in Chesapeake Bay (Table 4). The underestimation of wave attenuation in shallower water may arise because bed friction is insufficiently considered in the predictive model. In fact, the Dean (1978) model does not reflect the influence of elevation gradient. Because the drag coefficient given by Knuston et al. (1982) is an empirical value, it actually reflects the combined effect of bed friction and plant drag. Interaction between the bed and waves is greater in shallower water than in deeper water. In 
contrast, overestimation of wave attenuation in deeper water was probably the result of inundation of the plant canopy. The Dean (1978) model assumes that water depth is lower than plant height, that stem density is vertically unchanged, and that stems are rigid. In fact, stem density usually decreases with vertical distance increasing from the ground level (e.g., Fig. 2). According to our field observations, when water depth is higher than stem length, which is significantly lower than plant height (e.g., Knuston et al. 1982), the plant leaves float on the water surface; when water depth increased, all marsh vegetation is submerged and waves were found to propagate across the water surface. At high tides, the water depth of the marsh transect can reach 1.5-2 times higher than the average plant height in Eastern Chongming. As a result, the marsh plant canopy was usually submerged during spring high tides, which reduced wave attenuation by the vegetation. In Chesapeake Bay, water depth at high tides can also exceed average plant height (Knuston et al. 1982). Hence, at each marsh, a changing drag coefficient should be employed with respect to water depth for improving the prediction of wave attenuation. The greater the water depth relative to the stem length, the lower the drag coefficient should be employed. As shown in Fig. 8, when the drag coefficient 2 was replaced by a changing value of $1.3-3.8$, the root mean square error of wave attenuation decreased by $42 \%$.

\section{Conclusions}

The rate of wave attenuation over a zone of $S$. alterniflora marsh at the Yangtze Estuary was 1 to 2 magnitudes greater than over the adjacent mudflat. Although this difference is partly due to an increase in bed gradient across the marsh margin, more than $80 \%$ of the increase in the rate of wave attenuation was attributed to the presence of vegetation. Wave attenuation showed an exponentially decreasing trend with distance across the marsh. Due to the shoaling effect and a higher stem density closer to the bed, wave attenuation rate is inversely correlated to water depth. On average, the distance over which significant wave height was eliminated in the present study was $\sim 80 \mathrm{~m}$, compared with $\sim 30 \mathrm{~m}$ in a previous study of $S$. alterniflora marshes in the USA (Knuston et al. 1982). This difference between sites was probably due to the larger water depths and larger incident wave heights, combined with a smaller elevation gradient at the salt marsh in Eastern Chongming. At the same site, the stretch of marsh vegetation needed to eliminate the largest waves at spring high tides (under storm conditions) can exceed $100 \mathrm{~m}$. The wave attenuation rate by the introduced $S$. alterniflora is several times higher than that reported for the shorter, native pioneer vegetation in the Yangtze Estuary and along European coasts. This finding indicates that differences in wave attenuation rates can be significant among marsh vegetation species. Comparisons thus show that wave attenuation across salt marshes is determined by vegetation characteristics, hydrodynamics, and ground topography and can show marked spatial and temporal variations. The models by Dean (1978) and Knuston et al. (1982) can be employed to predict wave attenuation across marsh vegetation. However, our calculations show that it is essential to derive a suitable empirical drag coefficient, with respect to local plant characteristics, and hydrological and topographical conditions. The use of salt marshes for coastal defense requires sound knowledge of wave attenuation across the marsh area. Hence, there is a strong need for a more general understanding of how salt marshes attenuate waves in the field, under various hydrological and topographical conditions.

Acknowledgements This study was funded by the Natural Science Foundation of China $(41071014,40671017)$, the Ministry of Science and Technology of China (2010CB912502, 2008DFB90240), and the Programme of Strategic Scientific Alliances between China and the Netherlands (08-PSA-E-01). We also acknowledge the THESEUS project for supporting SKLEC and NIOO for research on the application of salt marshes for coastal defense. One anonymous reviewer and the associate editor are thanked for their comments and suggestions, which were valuable in improving earlier versions of this paper. We especially thank James Cloern, Editor-in-Chief, for his kindness in granting us the opportunity to revise an earlier version of this manuscript.

Open Access This article is distributed under the terms of the Creative Commons Attribution Noncommercial License which permits any noncommercial use, distribution, and reproduction in any medium, provided the original author(s) and source are credited.

\section{References}

Allen, J.R.L. 2000. Morphodynamics of Holocene salt marshes: a review sketch from the Atlantic and Southern North Sea coasts of Europe. Quaternary Science Reviews 19: 1155-1231.

Asano, T., and Y. Setoguchi. 1996. Hydrodynamic effects of coastal vegetation on wave damping. In Hydrodynamics, ed. A.T. Chwang, J.H.W. Lee, and D.Y.C. Leung, 1051-1056. Rotterdam: Balkema.

Barbier, E.B., E.W. Koch, B.R. Silliman, S.D. Hacker, E. Wolanski, J. Primavera, E.F. Granek, S. Polasky, S. Aswani, L.A. Cramer, D.M. Stoms, C.J. Kennedy, D. Bael, C.V. Kappel, G. M.E. Perillo, and D.J. Reed. 2009. Coastal ecosystem-based management with nonlinear ecological functions and values. Science 319. doi:10.1126/science. 1150349.

Bouma, T.J., M.B. De Vries, E. Low, G. Peralta, I.C. Tánczos, J. van de Koppel, and P.M.J. Herman. 2005a. Trade-offs related to ecosystem engineering: A case study on stiffness of emerging macrophytes. Ecology 86: 2187-2199.

Bouma, T.J., M.B. De Vries, E. Low, L. Kusters, P.M.J. Herman, I.C. Tánczos, A. Hesselink, S. Temmerman, P. Meire, and S. van Regenmortel. 2005b. Flow hydrodynamics on a mudflat and in salt marsh vegetation: identifying general relationships for habitat characterisations. Hydrobiologia 540: 259-274. 
Bouma, T.J., M.B. De Vries, and P.M.J. Herman. 2010. Comparing Ecosystem engineering efficiency of 2 plant species with contrasting growth strategies. Ecology 91(9): 2696-2704. doi:10.1890/09-0690.

Christiansen, T., P.L. Wiberg, and T.G. Milligan. 2000. Flow and sediment transport on a tidal salt marsh surface. Estuarrine, Coastal and Shelf Science 50: 315-331.

Dean, R.G., 1978. Effect of vegetation on shoreline erosional processes. Wetland Function and Values: The State of Our understanding, Proceedings of the National Symposium on Wetlands, American Water Resources Association. Minneapolis, MN. 415-426.

Douglas, B.C., M.S. Kearney, and S.P. Leatherman. 2001. Sea Level Rise. San Diego: Academic.

Eisma, D. 1998. Intertidal Deposits: River Mouth, Tidal Flats, and Coastal Lagoons, 459. Boca Raton: CRC.

Frey, R.W., and P.B. Basan. 1985. Coastal salt marshes. In Coastal Sedimentary Environments, ed. R.A. Davis, 101-159. New York: Springer.

Friedrichs, C.T., and J.E. Perry. 2001. Tidal salt marsh morphodynamics: A synthesis. Journal of Coastal Research 27: 7-37.

Goodwin, P., A.J. Mehta, and J.B. Zedler. 2001. Tidal wetland restoration: An introduction. Journal of Coastal Research 27: 1-6.

Knuston, P.L., R.A. Brochu, W.N. Seelig, and M. Inskeep. 1982. Wave damping in Spartina alterniflora marshes. Wetlands 2: 87-104.

Kurian, N.P., and M. Baba. 1987. Wave attenuation due to bottom friction across the Southwest Indian Continental Shelf. Journal of Coastal Research 3(4): 485-490.

Leggett, D.J., and M. Dixon. 1994. Management of the Essex salt marshesfor flood defence. In Wetlands Management, ed. R. Falconer and P. Goodwin, 232-245. London: ICE.

Leonard, L.A., and M.E. Luther. 1995. Flow hydrodynamics in tidal marsh canopies. Limnology and Oceanography 40(8): 1474-1484.

Leonard, L.A., and D.J. Reed. 2002. Hydrodynamics and sediment transport through tidal marsh canopies. Journal of Coastal Research 36: 459-469.

Möller, I. 2006. Quantifying saltmarsh vegetation and its effect on wave height dissipation: Results from a UK East coast saltmarsh. Estuarine, Coastal and Shelf Science 69: 337-351.

Möller, I., and T. Spencer. 2002. Wave dissipation over macro-tidal saltmarshes: Effects of marsh edge typology and vegetation change. Journal of Coastal Research SI 36: 506-521.
Möller, I., T. Spencer, and J.R. French. 1996. Wind wave attenuation over saltmarsh surface: Preliminary results from Norfolk, England. Journal of Coastal Research 12: 1009-1016.

Möller, I., T.R. Spence, J.R. French, D.J. Leggett, and M. Dixon. 1999. Wave transformation over salt marshes: a field and numerical modeling study from North Norfolk, England. Estuarine, Coastal and Shelf Science 49: 411-426.

Neumeier, U., and P. Ciavola. 2004. Flow resistance and associated sedimentary processes in a Spartina maritima salt marsh. Journal of Coastal Research 20: 435-447.

Reed, D.J. 2002. Sea-level rise and coastal marsh sustainability: geological and ecological factors in the Mississippi Estuary plain. Geomorphology 48: 233-243.

Roman, C.T., J.A. Peck, J.R. Allen, J.W. King, and P.G. Appleby. 1997. Accretion of a New England salt marsh in response to inlet migration, storms and sea-level rise. Estuarine, Coastal and Shelf Science 45: 717-727.

Sea-Bird Electronics Inc. 2007. SBE 26plus SEAGAUGE Wave and Tide Recorder User Manual, Version 009. Bellevue: SBE.

Shi, Z., J.S. Pethick, and K. Pye. 1995. Flow structure in and above the various heights of a saltmarsh canopy: a laboratory flume study. Journal of Coastal Research 11: 1204-1209.

Wayne, C.J. 1976. The effects of sea and marsh grass on wave energy. Coastal Research Notes 4: 6-8.

Yang, S.L. 1998. The role of Scirpus marsh in attenuation of hydrodynamics and retention of fine-grained sediment in the Yangtze Estuary. Estuarine, Coastal and Shelf Science 47: 227233.

Yang, S.L., P.X. Ding, and S.L. Chen. 2001. Changes in progradation rate of the tidal flats at the mouth of the Changejiang River, China. Geomorphology 38: 167-180.

Yang, S.L., M. Li, S.B. Dai, Z. Liu, J. Zhang, and P.X. Ding. 2006. Drastic decrease in sediment supply from the Yangtze River and its challenge to coastal wetland management. Geophysical Research Letters 33: L06408. doi:10.1029/2005GL025507.

Yang, S.L., H. Li, T. Ysebaert, T.J. Bouma, W.X. Zhang, Y.Y. Wang, P. Li, M. Li, and P.X. Ding. 2008. Spatial and temporal variations in sediment grain size in tidal wetlands, Yangtze Estuary: On the role of physical and biotic controls. Estuarine, Coastal and Shelf Science 77: 657-671. doi:10.1016/j.ecss.2007.10.024. 